\title{
SYNTHESIS, ANTIOXIDANT AND ANTI-INFLAMMATORY ACTIVITIES OF ETHYL 2-(2-CYANO-3- (SUBSTITUTED PHENYL)ACRYLAMIDO)-4,5-DIMETHYLTHIOPHENE-3-CARBOXYLATES
}

\author{
MADHAVI K*, SREE RAMYA G \\ Department of Pharmaceutical Chemistry, Institute of Pharmaceutical Technology, Sri Padmavati Mahila Visvavidyalayam \\ (Women's University), Tirupati - 517 502, Chittoor, Andhra Pradesh, India. Email: kuchanamadhavi@yahoo.co.in
}

Received: 05 March 2017, Revised and Accepted: 13 April 2017

\section{ABSTRACT}

Objective: Objective of the study was to synthesize and evaluate a series of novel compounds, ethyl 2-(2-cyano-3-(substituted phenyl)acrylamido)4,5-dimethylthiophene-3-carboxylates, for in vitro antioxidant and in vivo anti-inflammatory activities.

Methods: Ethyl 2-(2-cyano-3-(substituted phenyl)acrylamido)-4,5-dimethylthiophene-3-carboxylates were synthesized by knoevenagel condensation of active methylene group of ethyl 2-(2-cyanoacetamido)-4,5-dimethylthiophene-3-carboxylate with substituted benzaldehydes. The synthesized compounds were evaluated for their in vitro antioxidant properties in three different models, viz., reduction of 1,1-diphenyl-2-pycrylhydrazyl free radical, scavenging of nitric oxide free radical, and ferric ion-induced lipid peroxidation using rat brain homogenate. Few selected compounds with good antioxidant properties were pharmacologically evaluated for anti-inflammatory activity by carrageenan-induced rat paw edema model.

Results: Clean and efficient synthetic procedure was used for the preparation of series of compounds. The structures of synthesized compounds were confirmed by infrared, ${ }^{1} \mathrm{H}$ nuclear magnetic resonance and mass spectra. The antioxidant activity data revealed that the compounds of ethyl 2-(2-cyano-3-(substituted phenyl)acrylamido)-4,5-dimethylthiophene-3-carboxylate containing phenolic substitution showed greater antioxidant activity. Hence, the active compounds were evaluated for anti-inflammatory activity and found to possess good activity. The percentage inhibition of rat paw edema obtained for the evaluated compounds was in the range of 70.2-83.1, comparable to the standard drug diclofenac (85.0\%).

Conclusion: The use of inexpensive, eco-friendly and readily available reagents, easy work-up and high purity of products makes the procedure a convenient and robust method for the synthesis of title compounds. The compounds of ethyl 2-(2-cyano-3-(substituted phenyl)acrylamido)-4,5dimethylthiophene-3-carboxylate containing phenolic substitution showed greater antioxidant and anti-inflammatory activities.

Keywords: 2-Aminothiophene, Cyanoacetamide, Knoevenagel condensation, 2-Cyano-3-(substituted phenyl)acrylamides.

(c) 2017 The Authors. Published by Innovare Academic Sciences Pvt Ltd. This is an open access article under the CC BY license (http://creativecommons. org/licenses/by/4. 0/) DOI: http://dx.doi.org/10.22159/ajpcr.2017.v10i7.18290

\section{INTRODUCTION}

Thiophene is a five-membered sulfur-containing aromatic heterocyclic compound with the formula $\mathrm{C}_{4} \mathrm{H}_{4} \mathrm{~S}$. The name thiophene has been taken from the word theion, the Greek word for sulfur, and another Greek word phaino which means shining. Its structure can be found in certain natural products and incorporated in several pharmacologically active compounds [1]. Within this class of heterocyclic compounds, 2 -aminothiophene ring system and their substituted derivatives have attracted a great deal of interest over the years. These compounds were reported as phosphate PTP1B inhibitors [2], adenosine receptor $\mathrm{A}_{3}$ inhibitors [3], and serotonin receptor subtype 5- $\mathrm{HT}_{1 \mathrm{~A}}$ inhibitors [4]. They are also used as starting materials for the synthesis of dyes, agrochemicals and conducting polymers [5].

The substituted 2-aminothiophene ring system incorporated in several pharmacologically active compounds such as olanzapine, an antipsychotic drug and tinoridine, a potent nonsteroidal anti-inflammatory drug with antiperoxidative properties. Some of the molecules containing 2-aminothiophene structure are under development as selective allosteric enhancer of adenosine A1 receptor, which includes T-62, PD81723 and ATL525 [6]. In our laboratory, ethyl 2-(2-cyanoacetamido)4,5-dimethylthiophene-3-carboxylate was synthesized from 2-amino4,5-dimethylthiophene-3-carboxylate by a versatile method and reported as good analgesic agent with antioxidant properties [7]. The synthesized compound has two nucleophilic sites, methylene group carbon and amide nitrogen, open wide synthetic opportunities for further reactions. The reactivity order of methylene carbon is greater than the amide nitrogen and can undergo knoevenagel condensation with substituted benzaldehydes to give 2-cyano-3-(substituted phenyl) acrylamides. Further, various 2-cyano-3-(substituted phenyl)acrylamides were reported to possess diverse pharmacological activities, of which entacapone is now clinically used as antiparkinsonism drug [8-13].

In view of potential pharmacological activities of ethyl 2-(2-cyanoacetamido)-4,5-dimethylthiophene-3-carboxylate and 2-cyano-3-(substituted phenyl)acrylamides, it has been planned to synthesize a series of novel compounds, ethyl 2-(2-cyano-3-(substituted phenyl)acrylamido)-4,5-dimethylthiophene-3-carboxylates and to evaluate the synthesized compounds for the in vitro antioxidant and in vivo anti-inflammatory activities.

\section{EXPERIMENTAL}

Aldehydes procured from Sigma-Aldrich and SD fine chemicals. All other chemicals are of AR grade. Melting points were determined in open capillaries on a digital Stuart melting point apparatus and are uncorrected. Purity of the compounds was checked using the glass plates coated with Silica gel-G, and spots were detected by iodine vapor. The IR spectra recorded using KBr Pellets on a BRUKER infrared (IR) spectrophotometer $\left(\mathrm{cm}^{-1}\right) .{ }^{1} \mathrm{H}$ nuclear magnetic resonance (NMR) spectra recorded on Avance- $400 \mathrm{MHz}$ spectrometer using TMS as internal standard (chemical shifts in $\delta \mathrm{ppm}$ ) and mass spectra recorded on applied EI techniques on Shimadzu QP 2011 PLUS GC-MS system.

Animal experiments were carried out in accordance with the guidelines of CPCSEA and by the approval of the Institutional Animal Ethics Committee [Regd. No. 1677/PO/Re/2012/CPCSEA/26]. 
General procedure for synthesis of ethyl 2-(2-cyano-3-(substituted phenyl)acrylamido)-4,5-dimethylthiophene-3-carboxylates (Scheme 1, 3a-3k):

Ethyl 2-(2-cyanoacetamido)-4,5-dimethylthiophene-3-carboxylate (10 $\mathrm{mmol})$ and substituted benzaldehydes (11 mmol) were added to $50 \mathrm{ml}$ of toluene. To this mixture, $0.35 \mathrm{ml}$ piperidine and $1.3 \mathrm{ml}$ acetic acid were added and refluxed for 5-6 hrs. The completion of the reaction was monitored by performing thin-layer chromatography. Then, the reaction mixture was cooled to room temperature; the precipitate was separated by filtration and recrystallized with suitable solvent.

3a Ethyl 2-(2-cyano-3-phenylacrylamido)-4,5-dimethylthiophene-3carboxylate: mp. $230-232^{\circ} \mathrm{C}$; yield $75 \%$; IR (KBr) $v_{\text {max }}: 3423$ (N-H str), 2987, 2930, 2861 (C-H str), 2214 (C $\equiv N$ str), 1667 (ester C=0 str), 1591 (amide C=0 str), 1561, 1530, 1446 (C=C str), 1261 (C-O str) cm ${ }^{-1} ;{ }^{1} \mathrm{H}$ NMR $\left(\mathrm{CDCl}_{3}\right) \delta: 1.40-1.43\left(\mathrm{t}, 3 \mathrm{H}, \mathrm{CH}_{3}\right), 2.29-2.31\left(2 \mathrm{~s}, 6 \mathrm{H}, \mathrm{CH}_{3}\right), 4.43-4.48$ $\left(\mathrm{q}, 2 \mathrm{H},-\mathrm{CH}_{2}-\right), 7.70-7.78(\mathrm{~m}, 5 \mathrm{H}, \mathrm{Ar}), 8.30(\mathrm{~s}, 1 \mathrm{H},-\mathrm{CH}=), 12.32(\mathrm{~s}, 1 \mathrm{H}, \mathrm{NH})$ ppm; Mass m/z: $377(\mathrm{M}+\mathrm{Na})^{+}$.

3b Ethyl 2-(2-cyano-3-(4-chlorophenyl)acrylamido)-4,5dimethylthiophene-3-carboxylate: $\mathrm{mp} .227-228^{\circ} \mathrm{C}$; yield $85 \%$; IR (KBr)

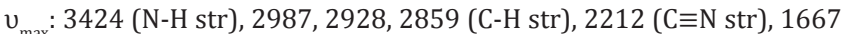
(ester C=0 str), 1599 (amide C=0 str), 1559, 1527, 1411 (C=C str), 1263
(C-0 str), 1096 (C-Cl str) cm ${ }^{-1} ;{ }^{1} \mathrm{H}$ NMR $\left(\mathrm{CDCl}_{3}\right) \delta: 1.39-1.43\left(\mathrm{t}, 3 \mathrm{H}, \mathrm{CH}_{3}\right)$, 2.29-2.31 (2s, 6H, $\left.\mathrm{CH}_{3}\right), 4.43-4.48\left(\mathrm{q}, 2 \mathrm{H},-\mathrm{CH}_{2}-\right)$, 7.49-7.51 and 7.937.95(2d, 4H, Ar), 8.35 (s, 1H, -CH=), 12.35 (s, 1H, NH) ppm; Mass m/z: $389\left(\mathrm{M}^{+}\right)$.

3c Ethyl 2-(2-cyano-3-(4-methylphenyl)acrylamido)-4,5-dimethyl thiophene-3-carboxylate: mp. $232-235^{\circ} \mathrm{C}$; yield 94\%; IR (KBr) v : 3444 (N-H str), 2989, 2924, 2858 (C-H str), 2213 (C $\equiv N$ str), 1664 (ester C=0 str), 1590 (amide $\mathrm{C}=0$ str), 1562, 1531, 1411 (C=C str), 1261(C-O str) $\mathrm{cm}^{-1}$; ${ }^{1} \mathrm{H}$ NMR $\left(\mathrm{CDCl}_{3}\right) \delta: 1.40-1.43\left(\mathrm{t}, 3 \mathrm{H}, \mathrm{CH}_{3}\right), 2.29-2.30\left(2 \mathrm{~s}, 6 \mathrm{H}, \mathrm{CH}_{3}\right)$, $2.44\left(\mathrm{~s}, 3 \mathrm{H}, \mathrm{CH}_{3}\right), 4.43-4.48\left(\mathrm{q}, 2 \mathrm{H},-\mathrm{CH}_{2}-\right), 7.31-7.33$ and $7.90-7.92(2 \mathrm{~d}, 4 \mathrm{H}$, $\mathrm{Ar}), 8.36(\mathrm{~s}, 1 \mathrm{H},-\mathrm{CH}=), 12.27(\mathrm{~s}, 1 \mathrm{H}, \mathrm{NH}) \mathrm{ppm}$; Mass m/z: $391\left(\mathrm{M}^{+} \mathrm{Na}\right)^{+}$

3d Ethyl 2-(2-cyano-3-(4-hydroxyphenyl)acrylamido)-4,5-dimethyl thiophene-3-carboxylate: mp. $298-300^{\circ} \mathrm{C}$; yield $90 \%$; IR $(\mathrm{KBr}) \mathrm{v}_{\mathrm{m}}$ : 3239 ( N-H str), 3131 (O-H str), 2990, 2926 (C-H str), 2212 (C $\equiv \mathrm{N} \mathrm{str}$ ), 1660 (ester $\mathrm{C}=0$ str), 1605 (amide $\mathrm{C}=0 \mathrm{str}$ ), 1562, 1510, 1435 (C=C str), 1230 (C-O str) cm ${ }^{-1} ;{ }^{1} \mathrm{H} \mathrm{NMR}\left(\mathrm{CDCl}_{3}\right) \delta: 1.33-1.37\left(\mathrm{t}, 3 \mathrm{H}, \mathrm{CH}_{3}\right), 2.23-$ $2.26\left(2 \mathrm{~s}, 6 \mathrm{H}, \mathrm{CH}_{3}\right), 4.33-4.38\left(\mathrm{q}, 2 \mathrm{H},-\mathrm{CH}_{2}-\right)$, 6.96-6.98 and7.98-8.01 (2d, $4 \mathrm{H}, \mathrm{Ar}), 8.29(\mathrm{~s}, 1 \mathrm{H},-\mathrm{CH}=), 10.83(\mathrm{~s}, 1 \mathrm{H}, \mathrm{OH}), 11.87$ (s, 1H, NH) ppm; Mass m/z: 369 (M-1).

3e Ethyl 2-(2-cyano-3-(4-hydroxy-3-methoxyphenyl)acrylamido)4,5-dimethyl thiophene-3-carboxylate: mp. $215-216^{\circ} \mathrm{C}$; yield $88 \%$; IR

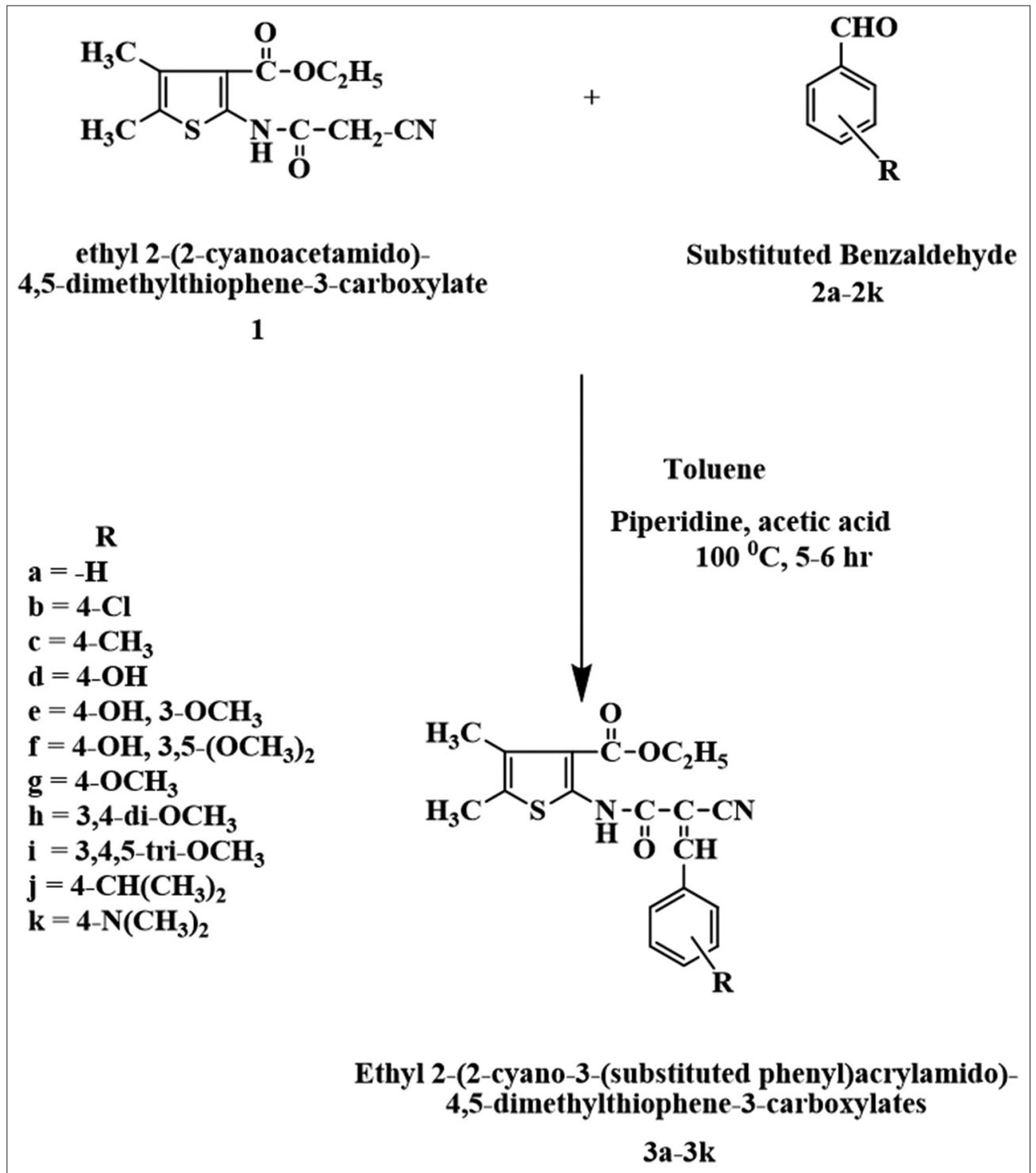

Scheme 1: Synthesis of ethyl 2-(2-cyano-3-(substituted phenyl)acrylamido)-4,5-dimethylthiophene-3-carboxylates 
(KBr) v : 3539 (N-H str), 3110 (O-H str), 2986, 2933, 2864 (C-H str), 2211 ( $\mathrm{C} \equiv \mathrm{N}$ str), 1664 (ester $\mathrm{C}=0 \mathrm{str}$ ), 1607 (amide $\mathrm{C}=0$ ) , 1565, 1512, 1436 ( $\mathrm{C}=\mathrm{C}$ str), 1256 (C-0 str), 1116 and 1028 (C-O-C asymmetric and symmetric) $\mathrm{cm}^{-1} ;{ }^{1} \mathrm{H} \mathrm{NMR}\left(\mathrm{CDCl}_{3}\right) \delta: 1.39-1.43\left(\mathrm{t}, 3 \mathrm{H}, \mathrm{CH}_{3}\right), 2.29-2.30(2 \mathrm{~s}$, $\left.6 \mathrm{H}, \mathrm{CH}_{3}\right), 3.99\left(\mathrm{~s}, 3 \mathrm{H}, \mathrm{OCH}_{3}\right), 4.42-4.48\left(\mathrm{q}, 2 \mathrm{H},-\mathrm{CH}_{2}-\right), 6.20(\mathrm{~s}, 1 \mathrm{H}, \mathrm{OH})$, 7.00-7.03 and 7.43-7.81 (m, 3H, Ar), $8.28(\mathrm{~s}, 1 \mathrm{H},-\mathrm{CH}=), 12.24(\mathrm{~s}, 1 \mathrm{H}$, NH) ppm; Mass m/z: 399 (M-1).

3 Ethyl 2-(2-cyano-3-(4-hydroxy-3,5-dimethoxyphenyl)acrylamido)4,5-dimethyl thiophene-3-carboxylate: mp. $245-246^{\circ} \mathrm{C}$; yield $80 \%$; IR (KBr) $v_{\text {max }}: 3464$ (N-H str), 3168 (O-H str), 2984, 2930, 2850 (C-H str), 2204 ( $\mathrm{C} \equiv \mathrm{N}$ str), 1661 (ester $\mathrm{C}=0 \mathrm{str}$ ), 1610 (amide $\mathrm{C}=0 \mathrm{str}$ ), 1561, 1503, 1456 (C=C str), 1246 (C-O str), 1158 and 1025 (-C-O-C asymmetric and symmetric) $\mathrm{cm}^{-1} ;{ }^{1} \mathrm{H}$ NMR $\left(\mathrm{CDCl}_{3}\right) \delta: 1.39-1.43(\mathrm{t}, 3 \mathrm{H}$, $\left.\mathrm{CH}_{3}\right), 2.29-2.30\left(2 \mathrm{~s}, 6 \mathrm{H}, \mathrm{CH}_{3}\right), 3.97\left(\mathrm{~s}, 6 \mathrm{H}, \mathrm{OCH}_{3}\right), 4.42-4.48\left(\mathrm{q}, 2 \mathrm{H},-\mathrm{CH}_{2}-\right)$, $6.10(\mathrm{~s}, 1 \mathrm{H}, \mathrm{OH}), 7.26-7.34(2 \mathrm{~s}, 2 \mathrm{H}, \mathrm{Ar}), 8.25(\mathrm{~s}, 1 \mathrm{H},-\mathrm{CH}=), 12.24(\mathrm{~s}, 1 \mathrm{H}$, $\mathrm{NH}) \mathrm{ppm}$; Mass m/z: $453(\mathrm{M}+\mathrm{Na})^{+}$.

$3 g$ Ethyl 2-(2-cyano-3-(4-methoxyphenyl)acrylamido)-4,5dimethylthiophene-3-carboxylate: mp. $228-229^{\circ} \mathrm{C}$; yield $90 \%$; IR (KBr)

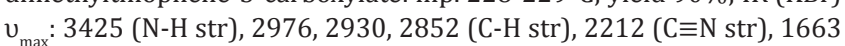
(ester C=0 str), 1590 (amide $\mathrm{C}=0 \mathrm{str}$ ), 1560, 1515, 1429 (C=C str), 1262 (C-O str), 1176 and 1019 (-C-O-C asymmetric and symmetric) $\mathrm{cm}^{-1} ;{ }^{1} \mathrm{H}$ NMR $\left(\mathrm{CDCl}_{3}\right)$ \&: 1.39-1.43 (t, 3H, $\left.\mathrm{CH}_{3}\right), 2.29-2.30\left(2 \mathrm{~s}, 6 \mathrm{H}, \mathrm{CH}_{3}\right), 3.90(\mathrm{~s}$, $\left.3 \mathrm{H}, \mathrm{OCH}_{3}\right), 4.43-4.48\left(\mathrm{q}, 2 \mathrm{H},-\mathrm{CH}_{2}-\right), 7.00-7.02$ and 8.00-8.02 (2d, $4 \mathrm{H}$, $\mathrm{Ar}), 8.32(\mathrm{~s}, 1 \mathrm{H},-\mathrm{CH}=), 12.22(\mathrm{~s}, 1 \mathrm{H}, \mathrm{NH}) \mathrm{ppm}$; Mass m/z: $407(\mathrm{M}+\mathrm{Na})^{+}$.

3h Ethyl 2-(2-cyano-3-(3,4-dimethoxyphenyl)acrylamido)-4,5dimethylthiophene-3-carboxylate: mp. $231-232^{\circ} \mathrm{C}$; yield $72 \%$; IR (KBr) $v_{\max }: 3145$ (N-H str), 2975, 2929, 2840 (C-H str), 2201 (C $\equiv N$ str), 1666 (ester C=0 str), 1634 (amide $\mathrm{C}=0$ str) 1564, 1505, 1413 (C=C str), 1258 (C-O str), 1144 and 1019 (-C-O-C asymmetric and symmetric) $\mathrm{cm}^{-1} ;{ }^{1} \mathrm{H}$ $\operatorname{NMR}\left(\mathrm{CDCl}_{3}\right) \delta: \delta 1.39-1.43\left(\mathrm{t}, 3 \mathrm{H}, \mathrm{CH}_{3}\right), 2.29-2.30\left(2 \mathrm{~s}, 6 \mathrm{H}, \mathrm{CH}_{3}\right), 3.97(\mathrm{~s}$, $\left.6 \mathrm{H}, \mathrm{OCH}_{3}\right), 4.42-4.48\left(\mathrm{q}, 2 \mathrm{H},-\mathrm{CH}_{2}-\right), 6.95-6.97$ and 7.49-7.78 (m, 3H, Ar), $8.29(\mathrm{~s}, 1 \mathrm{H},-\mathrm{CH}=), 12.24(\mathrm{~s}, 1 \mathrm{H}, \mathrm{NH}) \mathrm{ppm}$; Mass m/z: $413(\mathrm{M}-1)$.

3i Ethyl 2-(2-cyano-3-(3,4,5-trimethoxyphenyl)acrylamido)-4,5dimethylthiophene-3-carboxylate: mp. $193-194^{\circ} \mathrm{C}$; yield $80 \%$; IR (KBr) $v_{\max }: 3167$ (N-H str), 2982, 2937, 2841 (C-H str), 2204 (C $\equiv N$ str), 1659 (ester C=0 str), 1601 (amide $\mathrm{C}=0 \mathrm{str}$ ), 1559, 1532, 1429 (C=C str), 1248 (C-O str), 1122 and 1019 (-C-O-C asymmetric and symmetric) $\mathrm{cm}^{-1}$; ${ }^{1} \mathrm{H}$ NMR $\left(\mathrm{CDCl}_{3}\right) \delta: 1.39-1.43\left(\mathrm{t}, 3 \mathrm{H}, \mathrm{CH}_{3}\right), 2.29-2.31\left(\mathrm{~d}, 6 \mathrm{H}, \mathrm{CH}_{3}\right), 3.93-$ $3.96\left(2 \mathrm{~s}, 9 \mathrm{H}, \mathrm{OCH}_{3}\right), 4.42-4.48\left(\mathrm{q}, 2 \mathrm{H},-\mathrm{CH}_{2}-\right), 7.26-7.30(2 \mathrm{~s}, 2 \mathrm{H}, \mathrm{Ar}), 8.28$ $(\mathrm{s}, 1 \mathrm{H},-\mathrm{CH}=), 12.30(\mathrm{~s}, 1 \mathrm{H}, \mathrm{NH}) \mathrm{ppm}$; Mass m/z: $443(\mathrm{M}-1)$.

3j Ethyl 2-(2-cyano-3-(4-isopropylphenyl)acrylamido)-4,5dimethylthiophene-3-carboxylate: $\mathrm{mp} .172-173^{\circ} \mathrm{C}$; yield $78 \%$; IR (KBr)

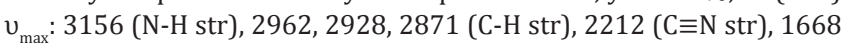
(ester $\mathrm{C}=0 \mathrm{str}$ ), 1588 (amide $\mathrm{C}=0 \mathrm{str}$ ), 1558, 1529, 1405 ( $\mathrm{C}=\mathrm{C} \mathrm{str}$ ), $1256(\mathrm{C}-0) \mathrm{cm}^{-1} ;{ }^{1} \mathrm{H}$ NMR $\left(\mathrm{CDCl}_{3}\right) \delta: 1.27-1.29\left(\mathrm{~d}, 6 \mathrm{H}, \mathrm{CH}\left(\mathrm{CH}_{3}\right)_{2}\right), 1.39-$ $1.43\left(\mathrm{t}, 3 \mathrm{H}, \mathrm{CH}_{3}\right), 2.29-2.30\left(2 \mathrm{~s}, 6 \mathrm{H}, \mathrm{CH}_{3}\right), 2.93-3.04$ (sep, $\left.1 \mathrm{H}, \mathrm{CH}\left(\mathrm{CH}_{3}\right)_{2}\right)$, 4.43-4.48 (q, 2H, $-\mathrm{CH}_{2}-$ ), 7.37-7.39 and 7.94-7.96 (2d, 4H, Ar), 8.37 (s, $1 \mathrm{H},-\mathrm{CH}=), 12.28(\mathrm{~s}, 1 \mathrm{H}, \mathrm{NH}) \mathrm{ppm} ;$ Mass m/z: $419(\mathrm{M}+\mathrm{Na})^{+}$.

3k Ethyl 2-(2-cyano-3-(4-(dimethylamino)phenyl)acrylamido)-4,5dimethylthiophene-3-carboxylate: mp. $261-263^{\circ} \mathrm{C}$; yield $78 \%$; IR (KBr) $u_{\max }: 3154$ (N-H str), 2986, 2917 (C-H str), 2202 (C $\equiv N$ str), 1659 (ester $\mathrm{C}=0$ str), 1608 (amide $\mathrm{C}=0 \mathrm{str}$ ), 1562, 1519, 1439 (C=C str), 1237 (C-O str) $\mathrm{cm}^{-1} ;{ }^{1} \mathrm{H} \mathrm{NMR}\left(\mathrm{CDCl}_{3}\right) \delta: 1.39-1.42\left(\mathrm{t}, 3 \mathrm{H}, \mathrm{CH}_{3}\right), 2.28-2.29(2 \mathrm{~s}, 6 \mathrm{H}$, $\mathrm{CH}_{3}$ ), $3.11\left(\mathrm{~s}, 6 \mathrm{H},-\mathrm{N}\left(\mathrm{CH}_{3}\right)_{2}\right), 4.42-4.48\left(\mathrm{q}, 2 \mathrm{H},-\mathrm{CH}_{2}-\right), 6.70-6.72$ and 7.93$7.95(2 \mathrm{~d}, 4 \mathrm{H}, \mathrm{Ar}), 8.21(\mathrm{~s}, 1 \mathrm{H},-\mathrm{CH}=), 12.07(\mathrm{~s}, 1 \mathrm{H}, \mathrm{NH}) \mathrm{ppm}$; Mass m/z: $420(\mathrm{M}+\mathrm{Na})^{+}$.

\section{In vitro antioxidant studies}

The synthesized compounds were evaluated for their in vitro antioxidant properties in three different models, viz., reduction of 1,1-diphenyl-2-pycrylhydrazyl (DPPH) free radical, scavenging of nitric oxide free radical, and ferric ion-induced lipid peroxidation using rat brain homogenate.

\section{Reduction of DPPH free radical}

DPPH is a nitrogen-centered free radical with an odd electron used to characterize the antioxidants. The delocalization of odd electron over the molecule as a whole makes it as a paramagnetic solid and when it is dissolved in absolute alcohol appears as a deep violet color solution with strong UV absorption at $517 \mathrm{~nm}$. DPPH radical can accept electron or hydrogen radical to become stable diamagnetic molecule, 1,1-diphenyl2-picrylhydrazine (DPPH-H), which is colorless or pale yellow. This property makes it suitable for spectrophotometric studies [14]. A radical scavenging antioxidant reacts with DPPH stable free radical and converts to DPPH-H. The change in the absorbance produced in this reaction has been used to measure antioxidant properties.

Ethanolic solutions of test compounds at $100 \mu \mathrm{M}$ concentration were added to $100 \mu \mathrm{M}$ DPPH in $95 \%$ ethanol. The test tubes containing reaction mixture were shaken vigorously and allowed to stand at room temperature for 20 minutes. The absorbance was measured at $517 \mathrm{~nm}$ in a UV-visible spectrophotometer [15]. Control experiment was carried out with solvent only, and ascorbic acid was used as reference standard. All the measurements were performed in triplicate, and the mean of triplicate measurements was used to calculate the percentage reduction of DPPH by the following formula.

\section{Percentage reduction of DPPH=[Control-Test $] /$ Control $\times 100$}

\section{Assay of nitric oxide free radical scavenging}

Sodium nitroprusside in aqueous solution at physiological $\mathrm{pH}$ spontaneously generates nitric oxide, which interacts with oxygen to produce nitrite ions. These nitrite ions can be estimated by diazotization reaction using Greiss reagent. Scavengers of nitric oxide compete with the oxygen leading to reduced production of nitric oxide [16].

Sodium nitroprusside $(10 \mu \mathrm{M})$ in phosphate buffer $\mathrm{pH} 7.4$ was incubated with $100 \mu \mathrm{M}$ concentration of test compounds dissolved in alcohol for 150 minutes at $25^{\circ} \mathrm{C}$ [17]. Then, $2 \mathrm{ml}$ of incubation solution was removed and added to $2 \mathrm{ml}$ of Griess reagent. The absorbance of chromophore formed during diazotization of nitrite with sulphanilamide and subsequent coupling with $\mathrm{N}$-naphthylethylenediamine was read at $546 \mathrm{~nm}$ [18]. The control experiment was conducted in an identical manner without test compound but with an equal amount of solvent. The percentage of scavenging activity was calculated with the following formula:

\section{Percentage of scavenging $=[$ Control-Test $] /$ Control $\times 100$}

\section{Ferric ion-induced lipid peroxidation}

A $10 \% \mathrm{w} / \mathrm{v}$ rat brain homogenate was prepared in $0.15 \mathrm{M} \mathrm{KCl}$ and centrifuged at $800 \mathrm{~g}$ for 10 minutes, and the supernatant was used immediately for the study of in vitro lipid peroxidation [19]. The incubation mixture contained in a final volume of $1.5 \mathrm{ml}$, brain homogenate $(0.5 \mathrm{ml}), \mathrm{KCl}(0.15 \mathrm{M})$, and ethanol $(10 \mu \mathrm{l})$ or test compound dissolved in ethanol. Peroxidation was initiated by adding ferric chloride to give the final concentration $100 \mu \mathrm{M}$. After incubation for 20 minutes at $37^{\circ} \mathrm{C}$, the reaction was stopped by adding $2 \mathrm{ml}$ ice-cold $0.25 \mathrm{M} \mathrm{HCl}$ containing $15 \%$ trichloroacetic acid, $0.38 \%$ thiobarbituric acid and $0.05 \%$ butylated hydroxytoluene. Following heating at $80^{\circ} \mathrm{C}$ for 15 minutes, samples were cooled and centrifuged at $1000 \mathrm{~g}$ for 10 minutes. The absorbance of the supernatant solution was measured at $532 \mathrm{~nm}$ [20]. The percentage inhibition of thiobarbituric acid reactive substances formed by test compounds was calculated by comparing with vehicle only experiments [21].

\section{Anti-inflammatory activity}

The synthesized compounds with good antioxidant properties were pharmacologically evaluated for anti-inflammatory activity by carrageenan rat paw edema model.

\section{Carrageenan-induced rat paw edema assay}

Carrageenan-induced rat paw edema is a biphasic response. The first phase is mediated through the release of histamines, serotonin 
and kinins, whereas the second phase is related to the release of prostaglandins and slow reacting substance which peak after $3 \mathrm{hrs}$ of Carrageenan injection [22]. Carrageenan edema model has fairly high specificity and it is a standard experimental model of acute inflammation. This model has given consistent dose response curves for the major anti-inflammatory drugs such as diclofenac, aspirin, phenylbutazone, and indomethacin.

The male Wistar rats weighing 150-180 g were divided into groups, one group consisting of six served as control, while the other groups of five animals received the test compound or standard drug. The rats were dosed $(100 \mathrm{mg} / \mathrm{kg})$ orally with test compounds $1 \mathrm{hr}$ before injection of $0.05 \mathrm{ml}$ of $1 \%$ suspension of carrageenan into the subplantar region of the rat hind paw. Additional groups were similarly treated with $100 \mathrm{mg} / \mathrm{kg}$ diclofenac to serve as positive control and $10 \mathrm{ml} / \mathrm{kg} 0.5 \%$ sodium carboxymethyl cellulose to serve as vehicle control. Initial paw volumes were measured by water displacement method immediately after carrageenan injection using digital plethysmograph. The paw volumes were again measured after 3 hrs. The average paw edema volumes for test group animals and positive control group were compared statistically with those of the vehicle control animals and expressed as percent edema inhibition [21].

\section{RESULTS AND DISCUSSION}

In our laboratory, a facile method has been developed for the synthesis of ethyl 2-(2-cyanoacetamido)-4,5-dimethylthiophene-3carboxylate from ethyl 2-amino-4,5-dimethylthiophene-3-carboxylate by cyanoacetylation with a versatile compound 1-cyanoacetyl3,5-dimethylpyrazole [7]. Ethyl 2-(2-cyanoacetamido)-4,5dimethylthiophene-3-carboxylate contains an active methylene group as nucleophilic site, hence a $\mathrm{C}=\mathrm{C}$ double bond was generated by knoevenagel condensation reaction with various substituted benzaldehydes $(2 \mathrm{a}-2 \mathrm{k})$ in the presence of toluene containing catalytic amounts of piperidine and acetic acid. The reaction was simple and completed within 5-6 hrs to yield a series of ethyl 2-(2-cyano3-(substituted phenyl)acrylamido)-4,5-dimethylthiophene-3carbxoylates (3a-3k) almost in pure form. However, they were purified by recrystallization with alcohol. The compounds obtained in good yields ranging from $72 \%$ to $94 \%$. The physical data of the synthesized compounds were given in Table 1 . The structures of the synthesized compounds were confirmed by IR, ${ }^{1} \mathrm{H}$ NMR, and mass spectra.

The IR spectra of final compounds showed an absorption band at 3539-3145 $\mathrm{cm}^{-1}$ indicative of $\mathrm{N}-\mathrm{H}$ stretching of an amide group. The absorption bands in the region of $2990-2840 \mathrm{~cm}^{-1}$ indicative of $\mathrm{C}-\mathrm{H}$ stretching and in the region of $2214-2202 \mathrm{~cm}^{-1}$ corresponds to $\mathrm{C} \equiv \mathrm{N}$ stretching. The absorption band corresponding to carbonyl group of ester and amide appeared in the region of $1667-1659 \mathrm{~cm}^{-1}$ and $1634-1588 \mathrm{~cm}^{-1}$, respectively. The absorption peaks at $1565-1411 \mathrm{~cm}^{-1}$ indicate the $\mathrm{C}=\mathrm{C}$ stretching vibrations. The absorption band representing C-O stretching was appeared in the region of $1263-1230 \mathrm{~cm}^{-1}$. The compounds containing phenolic hydroxyl group showed an absorption band in the region of $3168-3110 \mathrm{~cm}^{-1}$ indicative of $\mathrm{O}-\mathrm{H}$ stretching. The compounds with methoxy substitution exhibited absorption band in the region of $1176-1116 \mathrm{~cm}^{-1}$ and $1028-1019 \mathrm{~cm}^{-1}$ due to C-O-C asymmetric and symmetric stretching vibrations, respectively.

The NMR spectra of title compounds (3a-3k) showed triplet in the region of $\delta$ 1.33-1.43 due to methyl protons of ethyl ester and quartets in the region of $\delta$ 4.33-4.68 due to $-\mathrm{CH}_{2}$ - protons of ethyl ester. The spectra also revealed the presence of two singlets in the region of $\delta$ 2.23-2.31 due to the protons of two methyl groups of 4,5-dimethylthiophene ring. The spectra also exhibited multiplets in the region of $\delta 6.70-8.02$ assignable to aromatic protons. The spectra of the compounds showed singlets in the region of $\delta 8.21-8.40$ due to benzylidene protons and also singlets in the region of $\delta 12.07-12.35$ indicative of $\mathrm{NH}$ protons of amide group. The compounds containing methoxy group exhibited characteristic signals in the region of $\delta$ 3.90-3.97. The compound containing isopropyl group exhibited doublet and septet at $\delta$ 1.27-1.29 and $\delta$ 2.93-3.04, respectively. The methyl protons of dimethylamino derivative appeared as singlets in the region of $\delta$ 3.11. The disappearance of signal corresponding to active methylene protons of intermediate at $\delta 3.65$ and appearance of benzylidene protons at $\delta 8.21-8.40$ in all the NMR spectra of final compounds confirms the structures of title compounds.

The mass spectra of final compounds showed their characteristic molecular ion peak. Thus, the structures of the compounds were confirmed by IR, ${ }^{1} \mathrm{H}$ NMR and mass spectral data.

\section{In vitro antioxidant studies}

The synthesized compounds, ethyl 2-(2-cyano-3-(substituted phenyl) acrylamido)-4,5-dimethylthiophene-3-carbxoylates were evaluated for their in vitro antioxidant properties at $100 \mu \mathrm{M}$ concentration in three different models, viz., reduction of DPPH free radical, scavenging of nitric oxide free radical and ferric ion-induced lipid peroxidation using rat brain homogenate. The activity data are presented in Table 2.

The study revealed that the compounds with phenolic hydroxyl group ( $3 \mathrm{~d}, 3 \mathrm{e}$ and $3 \mathrm{f}$ ) exhibited greater antioxidant activity in all the three models when compared with other evaluated compounds. Among which, the compound 3f, ethyl 2-(2-cyano-3-(4-hydroxy-3,5dimethoxyphenyl)acrylamido)-4,5-dimethylthiophene-3-carboxylate showed highest activity. The reason may be due to the presence of two methoxy groups, ortho to phenolic hydroxyl group making the molecule as sterically hindered phenol. This observation is in confirmation with the literature that steric hindrance of phenolic moiety is one of the factors governing antioxidant efficiency [23]. The conversion of phenolic hydroxyl group to methoxy group as in compounds $3 \mathrm{~g}, 3 \mathrm{~h}$ and $3 \mathrm{i}$ resulted in reduction of antioxidant activity and indicated that the phenolic moiety is necessary to confer better antioxidant and radical scavenging properties. Further, the activity data revealed that the other evaluated compounds $3 \mathrm{a}, 3 \mathrm{~b}, 3 \mathrm{c}, 3 \mathrm{j}$, and $3 \mathrm{k}$ exhibited low to moderate antioxidant activity in all the three models.

Table 1: Physical data of ethyl 2-(2-cyano-3-(substituted phenyl) acrylamido)-4,5-dimethylthiophene-3-carboxylates

\begin{tabular}{|c|c|c|c|c|c|c|}
\hline Compound & $\mathbf{R}$ & Molecular formula & Molecular weight & Melting point $\left({ }^{\circ} \mathrm{C}\right)$ & Yield (\%) & $\mathbf{R}_{\mathrm{f}}^{*}$ \\
\hline $3 a$ & $\mathrm{H}$ & $\mathrm{C}_{19} \mathrm{H}_{18} \mathrm{~N}_{2} \mathrm{O}_{3} \mathrm{~S}$ & 354 & $230-232$ & 75 & 0.71 \\
\hline $3 b$ & $4-\mathrm{Cl}$ & $\mathrm{C}_{19}^{19} \mathrm{H}_{17}^{18} \mathrm{~N}_{2} \mathrm{O}_{3}^{3} \mathrm{SCl}$ & 389 & $227-228$ & 85 & 0.58 \\
\hline $3 c$ & $4-\mathrm{CH}_{3}$ & $\mathrm{C}_{20}^{19} \mathrm{H}_{20}^{17} \mathrm{~N}_{2}^{2} \mathrm{O}_{3}^{3} \mathrm{~S}$ & 368 & $232-235$ & 94 & 0.66 \\
\hline $3 d$ & $4-\mathrm{OH}^{3}$ & $\mathrm{C}_{19}^{20} \mathrm{H}_{18} \mathrm{~N}_{2}^{2} \mathrm{O}_{4}^{3} \mathrm{~S}$ & 370 & $298-300$ & 90 & 0.66 \\
\hline $3 e$ & $4-\mathrm{OH}, 3-\mathrm{OCH}_{3}$ & $\mathrm{C}_{20}^{19} \mathrm{H}_{20}^{18} \mathrm{~N}_{2}^{2} \mathrm{O}_{5}^{4} \mathrm{~S}$ & 400 & $215-216$ & 88 & 0.58 \\
\hline $3 \mathrm{f}$ & $4-\mathrm{OH}, 3,5-\mathrm{di}-\mathrm{OCH}_{3}$ & $\mathrm{C}_{21}^{20} \mathrm{H}_{22} \mathrm{~N}_{2}^{2} \mathrm{O}_{6}^{5} \mathrm{~S}$ & 430 & $245-246$ & 80 & 0.51 \\
\hline $3 g$ & $4-\mathrm{OCH}_{3}$ & $\mathrm{C}_{20}^{21} \mathrm{H}_{20}^{22} \mathrm{~N}_{2}^{2} \mathrm{O}_{4}^{6} \mathrm{~S}$ & 384 & $228-229$ & 90 & 0.61 \\
\hline $3 \mathrm{i}$ & 3,4,5-tri-OCH & $\mathrm{C}_{22}^{21} \mathrm{H}_{24} \mathrm{~N}_{2} \mathrm{O}_{6}^{5} \mathrm{~S}$ & 444 & $193-194$ & 80 & 0.83 \\
\hline $3 \mathrm{j}$ & $4-\mathrm{CH}\left(\mathrm{CH}_{3}\right)_{2}$ & $\mathrm{C}_{22} \mathrm{H}_{24} \mathrm{~N}_{2} \mathrm{O}_{3} \mathrm{~S}$ & 396 & $172-173$ & 78 & 0.91 \\
\hline $3 \mathrm{k}$ & $4-\mathrm{N}\left(\mathrm{CH}_{3}\right)_{2}$ & $\mathrm{C}_{21} \mathrm{H}_{23} \mathrm{~N}_{3} \mathrm{O}_{3} \mathrm{~S}$ & 397 & $261-263$ & 78 & 0.63 \\
\hline
\end{tabular}

Solvent system - 4:1 ratio of benzene and ethyl acetate 
Table 2: In vitro antioxidant activity of ethyl 2-(2-cyano-3-(substituted phenyl) acrylamido)-4,5-dimethylthiophene-3-carboxylates

\begin{tabular}{|c|c|c|c|c|}
\hline Compound & $\mathbf{R}$ & $\%$ Reduction of DPPH & $\%$ Inhibition of nitric oxide & $\%$ inhibition lipid peroxidation \\
\hline $3 a$ & $\mathrm{H}$ & 33.1 & 55.5 & 33.7 \\
\hline $3 \mathrm{~b}$ & 4-Cl & 33.3 & 52.3 & 16.6 \\
\hline $3 c$ & $4-\mathrm{CH}_{3}$ & 44.2 & 34.9 & 18.8 \\
\hline $3 \mathrm{~d}$ & $4-\mathrm{OH}^{3}$ & 64.3 & 76.9 & 58.4 \\
\hline $3 e$ & $4-\mathrm{OH}, 3-\mathrm{OCH}_{3}$ & 65.9 & 73.8 & 64.1 \\
\hline $3 \mathrm{f}$ & $4-\mathrm{OH}, 3,5-\mathrm{di}-\mathrm{OCH}_{3}$ & 74.6 & 82.5 & 72.8 \\
\hline $3 g$ & $4-\mathrm{OCH}_{3}$ & 15.6 & 33.3 & 17.7 \\
\hline $3 \mathrm{~h}$ & $3,4-\mathrm{di}-\mathrm{OCH}_{3}$ & 17.2 & 37.3 & 15.4 \\
\hline $3 \mathrm{i}$ & 3,4,5-tri- $\mathrm{OCH}_{3}$ & 32.7 & 41.2 & 27.9 \\
\hline $3 j$ & $4-\mathrm{CH}\left(\mathrm{CH}_{2}\right)_{2}{ }^{3}$ & 19.5 & 38.0 & 23.0 \\
\hline $3 \mathrm{k}$ & $4-\mathrm{N}\left(\mathrm{CH}_{3}\right)_{2}^{32}$ & 31.7 & 53.1 & 13.2 \\
\hline Standard & Ascorbic acid & 77.08 & 89.6 & - \\
\hline
\end{tabular}

Table 3: Anti-inflammatory activity of

ethyl 2-(2-cyano-3-(substituted phenyl) acrylamido)- 4,5-dimethylthiophene-3-carboxylates

\begin{tabular}{lll}
\hline Compound & R & Edema inhibition (\%) \\
\hline $3 \mathrm{~d}$ & $4-\mathrm{OH}$ & $70.2^{*}$ \\
$3 \mathrm{e}$ & $4-\mathrm{OH}, 3-\mathrm{OCH}_{3}$ & $83.1^{*}$ \\
3f & $4-\mathrm{OH}, 3,5-\left(\mathrm{OCH}_{3}\right)_{2}$ & $75.4^{*}$ \\
Standard & Diclofenac & $85.0^{*}$ \\
\hline
\end{tabular}

*Statistically significant $(\mathrm{p}<0.05$ Mann-Whitney test)

\section{Anti-inflammatory activity}

The active compounds among the ethyl 2-(2-cyano-3-(substituted phenyl)acrylamido)-4,5-dimethylthiophene-3-carboxylates (Compounds $3 \mathrm{~d}, 3 \mathrm{e}$ and $3 \mathrm{f}$ ) were screened for anti-inflammatory activity by the carrageenan-induced rat paw edema assay at a dose of $100 \mathrm{mg} / \mathrm{kg}$, p.o. The activity data are presented in Table 3 .

The results revealed that all the tested compounds possess good anti-inflammatory activity. Among the evaluated compounds, ethyl 2-(2-cyano-3-(4-hydroxy-3-methoxyphenyl)acryla mido)-4,5dimethylthiophene-3-carboxylate (compound $3 \mathrm{e}$ ) was found to be potent, and the inhibition of rat paw edema was $83.1 \%$, comparable to the standard drug, Diclofenac (85.0\%). The greater activity of this compound may be attributed to its physiological concentration and pharmacokinetic properties, which include absorption, distribution, metabolism, and excretion. Further, the compound 3f (4-hydroxy-3,5dimethoxy derivative) and the compound 3d (4-hydroxy derivative) were also found to have statistically significant edema inhibition values $75.4 \%$ and $70.2 \%$, respectively. The better anti-inflammatory activity exhibited by the evaluated compounds may be due to the redox properties of phenolic hydroxyl group present in their structures.

\section{CONCLUSION}

An eco-friendly and easy method has been used to synthesize the title compounds. The method includes mild reaction conditions and easy work-up procedure for the isolation of products. The reaction led to the expected products with high yield and in all most all cases the products obtained in pure form.

The present research work revealed that the compounds of ethyl 2-(2-cyano-3-(substituted phenyl)acrylamido)-4,5-dimethylthiophene3-carboxylate containing phenolic substitution showed greater antioxidant activity in all three different models. This clearly indicates that the phenolic moiety of these compounds confers antioxidant and radical scavenging properties. These active compounds also exhibited statistically significant anti-inflammatory activity in carrageenan rat paw edema model. The anti-inflammatory activity of phenolic compounds is most likely mediated, at least in part, by their antioxidant or redox mechanism. Hence, these compounds can be developed as useful therapeutic agents after establishing their safety pharmacology and toxicity profile.

\section{REFERENCES}

1. Mishra R, Jha KK, Kumar S, Tomer I. Synthesis, properties and biological activity of thiophene: A review. Pharm Chem 2011;3(4):38-54.

2. Iversen LF, Andersen HS, Branner S, Mortensen SB, Peters GH, Norris K, et al. Structure-based design of a low molecular weight, nonphosphorus, nonpeptide, and highly selective inhibitor of proteintyrosine phosphatase 1B. J Biol Chem 2000;275(14):10300-7.

3. Göblyös A, Ijzerman AP. Allosteric modulation of adenosine receptors. Purinergic Signal 2009;5(1):51-61.

4. Pessoa-Mahana H, Araya-Maturana R, Saitz CB, Pessoa-Mahana DC. A synthetic overview of new molecules with 5-HT1A binding affinities. Mini Rev Med Chem 2003;3(2):77-93.

5. Chavan SS, Pedgaonkar YY, Jadhav AJ, Degani MS. Microwave accelerated synthesis of 2-aminothiophene in ionic liquid via three component Gewald reaction. Indian J Chem 2012;51B:653-7.

6. Huang Y, Doemling A. The Gewald multi component reaction. Mol Divers 2011;15(1):3-33.

7. Madhavi K, Sudeepthi P. Synthesis of cyanoacetylated derivatives some heteroaryl amines as analgesic and antioxidant agents. Int J Pharm Sci Nanotechnol 2013;5(4):1879-84.

8. Zhou W, Li HB, Xia CN, Zheng XM, Hu WX. The synthesis and biological evaluation of some caffeic acid amide derivatives: E-2cyano-(3-substituted phenyl)acrylamides. Bioorg Med Chem Lett 2009;19(7):1861-5.

9. Poradosu E, Gazit A, Reuveni H, Levitzki A. Alpha-cyanocinnamide derivatives: A new family of non-peptide, non-sulfhydryl inhibitors of Ras farnesylation. Bioorg Med Chem 1999;7(8):1727-36.

10. Tamiz AP, Whittemore ER, Schelkun RM, Yuen PW, Woodward RM, Cai SX, et al. N-(2-(4-hydroxyphenyl)ethyl)-4-chlorocinnamide: A novel antagonist at the $1 \mathrm{~A} / 2 \mathrm{~B}$ NMDA receptor subtype. Bioorg Med Chem Lett 1998;8(2):199-200.

11. Katsumi I, Kondo H, Fuse Y, Yamashita K, Hidaka T, Hosoe K, et al. Studies on styrene derivatives. II. Synthesis and antiinflammatory activity of 3,5-di-tert-butyl-4-hydroxystyrenes. Chem Pharm Bull (Tokyo) 1986;34(4):1619-27.

12. Madhavi K. Synthesis and in vitro antioxidant activity of substituted $\alpha$-cyano-N-(5-methylisoxazol-3yl)cinnamides. World J Pharm Pharm Sci 2014;3(6):1800-8.

13. Madhavi K, Ramanamma KV. Synthesis and evaluation of ethyl 2-(2-cyano-3-(substituted phenyl)acrylamido)-4,5,6,7tetrahydrobenzo[b]thiophene-3-carboxylates for anti-oxidant and antibacterial activities. Int $J$ Curr Microbiol Appl Sci 2016;5(1):364-75.

14. Kadam VJ, Joshi YM, Sawant HP, Jadav TA. Free radical scavenging activity of aqueous solution of black salt. Int J Pharm Pharm Sci 2010;2(2):95-6.

15. Blois MS. Antioxidant determination by the use of a stable free radical. Nature 1958;181:1199-200.

16. Marcocci L, Packer L, Droy-Lefaix MT, Sekaki A, Gardès-Albert M. Antioxidant action of Ginkgo biloba extract EGb 761. Methods Enzymol 1994;234:462-75

17. Narkhede A, Gill J, Thakur K, Singh D, Singh E, Kulkarni O, et al. Total phenolic content and free radical quenching potential of Dioscorea alata L. Tubers. Int J Pharm Pharm Sci 2013;5(3):866-96. 
18. Sreejayan, Rao MNA. Nitric oxide scavenging by curcuminoids. J Pharm Pharmacol 1997;49(1):105-7.

19. Sharma OP. Antioxidant activity of curcumin and related compounds. Biochem Pharmacol 1976;25(15):1811-2

20. Sreejayan, Rao MNA. Curcuminoids as potent inhibitors of lipid peroxidation. J Pharm Pharmacol 1994;46(12):1013-6.

21. Madhavi K, Bharathi K, Prasad KVSRG. Synthesis and evaluation of 3-methyl-4-nitro-5-(substitutedstyryl)isoxazoles for antioxidant and antiinflammatory activities. Res J Pharm Biol Chem Sci 2010;1(4):1073-82.

22. Winter CA, Risley EA, Nuss GW. Carrageenin-induced edema in hind paw of the rat as an assay for antiiflammatory drugs. Proc Soc Exp Biol Med 1962;111:544-7.

23. Pospišil J. Antioxidants: Hindered Phenols. Netherlands: Springer; 1998. 